\title{
Latitudinal patterns in the concentrations of biologically utilised elements in the surface ocean
}

Daisy Pickup ${ }^{1}$, Toby Tyrrell ${ }^{1}$

${ }^{1}$ Ocean and Earth Science, University of Southampton, Southampton SO14 3ZH, UK

5 Correspondence to: ddp1n15@ soton.ac.uk

\begin{abstract}
Understanding of controls on the spatial distributions of chemical elements in the surface ocean has improved over time. Macronutrients were understood first, followed by dissolved inorganic carbon and alkalinity. Utilising data collected in the Atlantic by the ongoing GEOTRACES programme, controls can now start to be investigated for other elements. Here we investigate the generality of the rule that, in surface waters, higher concentrations occur at higher latitudes. Our analyses of Atlantic GEOTRACES data show that, after salinity normalisation, all biologically utilised elements except iron follow this rule $(\rho \geq 0.45)$. Most elements (nitrate, phosphate, cadmium, barium, and nickel) are even more strongly correlated $(\rho>0.6)$ with latitude. We attribute this pattern to upwelling and/or entrainment of deep water at high latitudes. Although only Atlantic data was analysed here, we predict that this rule will be found to hold true for all oceans in which surface and deep waters exchange more readily at high latitudes. The rule does not hold in the central western Arctic Ocean, where a year-round strong halocline prevents exchange of surface and deep waters.
\end{abstract}

\section{Introduction}

Macronutrients: The first distributions to start to be understood were those of the macronutrients nitrate, phosphate and silicate. The main features of their global distributions became apparent as: (1) reliable techniques for measuring concentrations were developed (e.g. Strickland and Parsons, 1972; Gordon et al., 1993), and (2) the first global datasets (of trustworthy data) were accumulated (e.g. Brewer et al., 1986; Moore, 1984). One main feature of the global pattern was realised early on - that macronutrient concentrations in the open ocean are generally higher towards the poles and lower at low latitudes (Levitus et al., 1993). There is a difference between low and mid latitudes (where, away from upwelling regions and river mouths, concentrations of macronutrients are typically low at all times of year) and high latitudes (where concentrations are either high in all seasons or else are high in winter and low in summer) (Takahashi et al. 1993; Conkright et al. 2000). Although conventional techniques struggled previously to measure phosphate accurately at lower concentrations, emerging datasets of nanomolar measurements only serve to reinforce this picture of a general low-latitude vs high-latitude divide (Martiny et al 2019).

The main driver of this general pattern in macronutrients is upwelling. It was established in the 1990's and 2000's that the Southern Ocean and subarctic North Pacific are both iron limited (de Baar et al., 2005; Boyd et al., 2007) and that this is the reason for the year-round high levels of residual nitrate, phosphate and silicate in surface waters. Furthermore, the cause of the iron-limitation in these regions is tied to upwelling, because deep ocean water (prior to being upwelled) is more deplete in iron relative to phytoplankton need (more strongly iron-limited than nitrate- or phosphate-limited) (Moore et al., 2016). Therefore, when phytoplankton blooms take place in HNLC (High Nutrient, Low Chlorophyll) regions following upwelling or deep winter mixing, iron runs out first and large amounts of macronutrients are left behind (Moore et al., 2016). The locations of the three main HNLC areas, the Southern Ocean, subarctic North Pacific and eastern Equatorial Pacific, all coincide with places where deep water is brought to the surface. 
https://doi.org/10.5194/bg-2020-371

Preprint. Discussion started: 19 October 2020

(c) Author(s) 2020. CC BY 4.0 License.

Alkalinity: Because of interest in the ocean's role in climate through its uptake of carbon dioxide from the atmosphere, large datasets of two other biogeochemical variables, DIC and alkalinity, have also been accumulated over the last 20 years. The first large global data sets containing alkalinity data (GLODAP and GLODAPv2; Olsen et al., 2016, 2019; Key et al., 2015) have shown

40 a more complicated picture for alkalinity than for macronutrients. It is apparent that raw (untransformed) alkalinity data does not show a strong correlation with latitude. Instead it exhibits a more complex distribution in the surface ocean, with highest values in the subtropical gyres, lower values close to the Equator and intermediate values towards the poles (Lee et al., 2006; Millero et al., 1998; Takahashi et al., 2014; Carter et al., 2014). Data analysis reveals a strong correlation with salinity (Millero et al., 1998; Friis et al., 2003; Jiang et al., 2014; Fry et al., 2015); high alkalinity values co-occur with high salinity values in the subtropical gyres

45 because both are produced by an excess of evaporation over precipitation. Evaporation (removal of fresh water containing no dissolved ions) raises the concentrations of all the dissolved elemental constituents left behind in seawater and therefore also raises total alkalinity (TA), because TA is a weighted sum of ionic concentrations.

Although not evident in unprocessed alkalinity data, a hidden high-latitude elevation is revealed when evaporation/precipitation

50 effects are removed (Fry et al., 2015). Moreover, when the effects of other processes known to influence alkalinity are also removed, to leave behind a tracer controlled only by calcium carbonate production and upwelling of dissolution-affected deep waters, it is seen to be upwelling that drives the high latitude elevation in salinity normalised TA (nTA) (Fry et al., 2015). This effect is masked in maps of TA but is apparent in maps of nTA and of related tracers such as potential alkalinity (Takahashi et al., 2014) and Alk* (Fry et al., 2015).

55

Dissolved inorganic carbon (DIC): Understanding of the distribution of DIC in surface waters has advanced at the same time as that of TA. A low-latitude to high-latitude gradient is apparent in non-normalised DIC data (Lee et al., 2000; Key et al., 2004; Takahashi et al., 2014) and even more strikingly apparent in salinity-normalised data (nDIC) (Wu et al., 2019). This latitudinal pattern has traditionally (e.g. Follows and Williams, 2011) been attributed to the temperature dependence of $\mathrm{CO}_{2}$ solubility (cold

60 water holds more $\mathrm{CO}_{2}$ gas than warm water; if both are in equilibrium with the same atmospheric $\mathrm{CO}_{2}$; in addition, seawater with higher $\mathrm{CO}_{2}$ also has higher DIC, all else being equal). A recent analysis (Wu et al., 2019) has shown, however, that the latitudinal gradient is driven in more or less equal part by upwelling/entrainment as it is by temperature-induced solubility variation.

Most recently, higher surface nickel concentrations at either end of an Atlantic-long transect have been reported (Middag et al., 2020).

This new understanding of controls on DIC, alkalinity and macronutrients, as well as the recent nickel observations, raise the question as to whether there is a general pattern for all biologically utilised elements. Given that: (1) $\mathrm{NO}_{3}, \mathrm{PO}_{4}, \mathrm{SiO}_{4}$, DIC, TA and $\mathrm{Ni}$ all show tendencies towards elevated values at high latitudes, and (2) in all cases except Ni this has been attributed to deep

70 water inputs, then it is reasonable to ask whether this is a general pattern that holds true for all biologically utilised constituents in seawater. In this paper we investigate the hypothesis that:

"All bioutilised elements are present at higher concentrations in high latitude than in low latitude surface waters" 
75 where bioutilised elements are defined here to be those which are taken up from surface water by organisms and which, as a result, increase in concentration with depth in the ocean. We distinguish here between bioutilised and biounutilised elements. These 2 categories map onto the 3 categories of an earlier scheme (Broecker and Peng, 1982): our bioutilised category encompasses both biolimiting and biointermediate categories of the earlier scheme; our biounutilised corresponds to their biounlimiting. In this study we do not care whether elements are limiting nutrients for biological production, we care only whether (1) an element is transported

80 to depth by the particle flux, and (2) this gives rise to a vertical gradient in the concentration of that element. Following the earlier scheme, some essential elements for plankton growth, such as manganese (Raven, 1990), are in this way classified as biounutilised, because their uptake and vertical transport does not result in a vertical gradient of increasing concentration with depth (Fig. 1; see also Sarmiento and Gruber, 2006). Conversely, some elements are classified here as bioutilised even though they are not required by plankton but rather are taken up "by accident" because of their chemical similarity to useful elements (for instance Ge, which is taken up inadvertently by diatoms in place of $\mathrm{Si}$ (Azam and Volcani, 1981), and increases with depth as a result (Sarmiento and Gruber, 2006)).
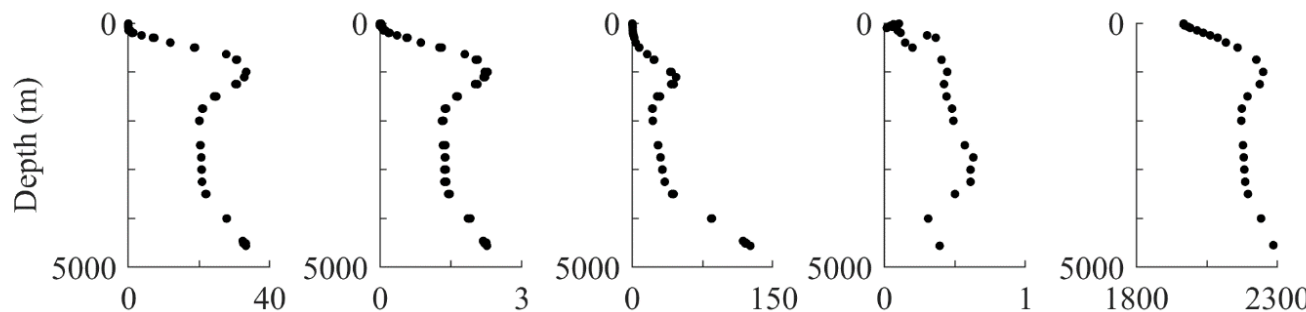

$\mathrm{nNO}_{3}\left(\mu \mathrm{mol} \mathrm{kg}^{-1}\right) \mathrm{nPO}_{4}\left(\mu \mathrm{mol} \mathrm{kg}^{-1}\right) \mathrm{nSiO}_{4}\left(\mu \mathrm{mol} \mathrm{kg}^{-1}\right) \quad \mathrm{nFe}\left(\mathrm{nmol} \mathrm{kg}^{-1}\right) \quad \mathrm{nDIC}\left(\mu \mathrm{mol} \mathrm{kg}^{-1}\right)$
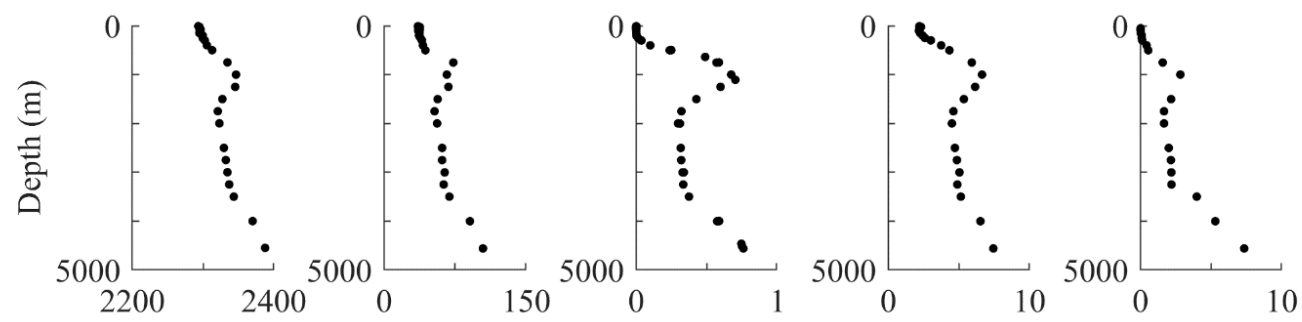

nTA $\left(\mu \mathrm{mol} \mathrm{kg}^{-1}\right) \quad \mathrm{nBa}\left(\mathrm{nmol} \mathrm{kg}^{-1}\right) \quad \mathrm{nCd}\left(\mathrm{nmol} \mathrm{kg}{ }^{-1}\right)$
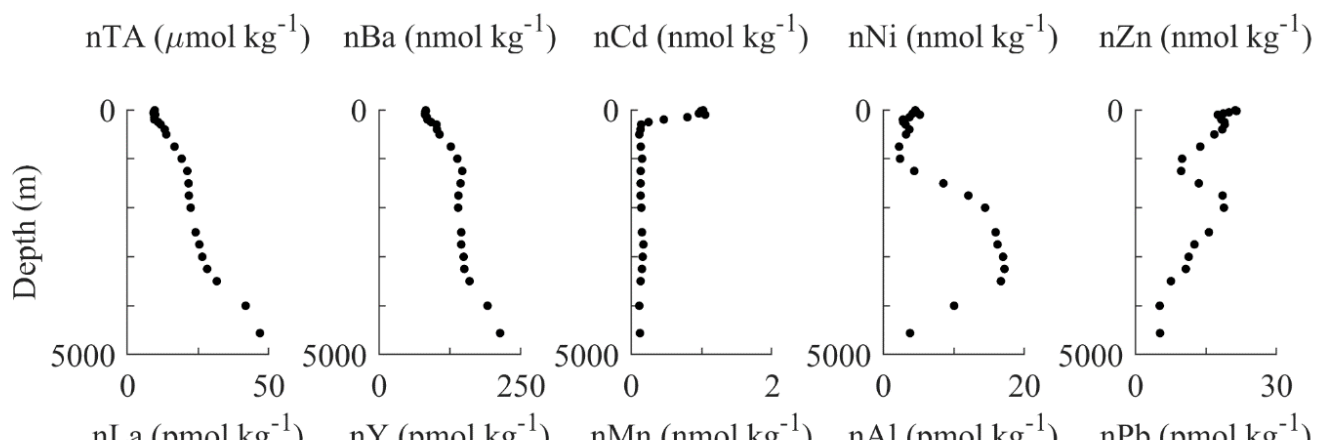

$\mathrm{nLa}\left(\mathrm{pmol} \mathrm{kg}{ }^{-1}\right) \quad \mathrm{nY}\left(\mathrm{pmol} \mathrm{kg}{ }^{-1}\right) \quad \mathrm{nMn}\left(\mathrm{nmol} \mathrm{kg}{ }^{-1}\right) \quad \mathrm{nAl}\left(\mathrm{pmol} \mathrm{kg}^{-1}\right) \quad \mathrm{nPb}\left(\mathrm{pmol} \mathrm{kg}^{-1}\right)$

Figure 1: Depth profiles for elements in the Atlantic Ocean. Data from GEOTRACES IDP2017v2, cruise GA02, station $33^{\circ} \mathrm{W} 22^{\circ} \mathrm{S}$. The prefix ' $n$ ' indicates salinity normalisation of concentrations.

90 Here we use data from the international GEOTRACES programme to explore the extent to which this hypothesis holds true (for instance, as just described, we know it to be true for nTA but not so much for TA). GEOTRACES is the first programme to make 
a global survey of the distributions of a large number of different elements, including trace elements and micronutrients as well as the more commonly measured variables. Here we look to see if the rule of high latitude surface enrichment applies also to the wider suite of GEOTRACES variables.

\section{Methods}

An earlier global survey campaign (WOCE, the World Ocean Circulation Experiment (Chapman, 1998]) measured macronutrients $\left(\mathrm{NO}_{3}, \mathrm{PO}_{4}, \mathrm{SiO}_{4}\right)$ and carbonate chemistry (e.g. DIC \& TA) on a global scale. Large data syntheses now exist for macronutrients (WOCE, WOA) and carbonate chemistry (GLODAP) (Olsen et al., 2016, 2019; Key et al., 2015). GEOTRACES is the first programme to measure a larger number of different biogeochemical variables in a comprehensive manner on a global scale. The

100 GEOTRACES second Intermediate Data Product (IDP2017v2) contains bottle data from 39 cruises, collected during the period 2007 to 2014. Only dissolved concentration data is used here; particulate concentrations are not included in our analyses. The recommended methods and protocols used to measure the different dissolved element concentrations are included in the GEOTRACES cookbook (available at: https://www.geotraces.org/cookbook). Subsequent to collection, the data was subjected to quality control procedures and, where such procedures indicated systematic offsets, adjustment (Schlitzer et al., 2018). Table 1 shows which elements were included in our study and on which GEOTRACES cruises they were measured. In this study we only included those GEOTRACES cruises for which final data has been released (the programme is part-way through). At the time of writing, sufficient GEOTRACES data to test the hypothesis of this paper was only available for the Atlantic; for this reason, data from other ocean basins is not considered further here. Figure 2 shows the geographical distribution of the Atlantic data for the various elements.

Table 1: GEOTRACES sections and elements measured on them. Only the cruises and elements used in this study are shown here.

\begin{tabular}{|c|c|c|}
\hline Section & Dates & Elements analysed \\
\hline GA01 & $15 / 05 / 2014-30 / 06 / 2014$ & $\mathrm{Al}, \mathrm{Pb}$ \\
\hline GA02 & $\begin{array}{l}28 / 04 / 2010-26 / 05 / 2010 \\
11 / 06 / 2010-08 / 07 / 2010 \\
01 / 03 / 2011-07 / 04 / 2011\end{array}$ & $\begin{array}{l}\mathrm{Al}, \mathrm{Ba}, \mathrm{Cd}, \mathrm{DIC}, \mathrm{Fe}, \mathrm{La}, \mathrm{Pb}, \mathrm{P}, \mathrm{SiO}_{4,} 115 \\
\mathrm{TA}, \mathrm{Y}, \mathrm{Zn}\end{array}$ \\
\hline GA03 & $\begin{array}{l}15-10 / 2010-04 / 11 / 2010 \\
06 / 11 / 2011-11 / 12 / 2011\end{array}$ & $\mathrm{Al}, \mathrm{P}, \mathrm{SiO}_{4}$ \\
\hline GA04 & $\begin{array}{l}14 / 05 / 2013-05 / 06 / 2013 \\
13 / 07 / 2013-25 / 07 / 2013 \\
25 / 07 / 2013-11 / 08 / 2013 \\
05 / 05 / 2013-01 / 06 / 2013\end{array}$ & $\mathrm{Al}, \mathrm{Cd}, \mathrm{La}, \mathrm{Y}, \mathrm{Zn}$ \\
\hline GA06 & 07/02/2011 - 19/03/2011 & $\mathrm{Al}, \mathrm{P}, \mathrm{SiO}_{4}$ \\
\hline GA10 & $18 / 10 / 2010-22 / 11 / 2010$ & $\begin{array}{l}\mathrm{Al}, \mathrm{Ba}, \mathrm{Cd}, \mathrm{DIC}, \mathrm{Fe}, \mathrm{La}, \mathrm{Pb}, \mathrm{P}, \mathrm{SiO}_{4}, \\
\mathrm{TA}, \mathrm{Zn}\end{array}$ \\
\hline GAc01 & $16 / 11 / 2007-13 / 12 / 2007$ & $\mathrm{Fe}, \mathrm{La}, \mathrm{P}, \mathrm{SiO}_{4}$ \\
\hline GIPY04 & & $\begin{array}{l}\mathrm{Al}, \mathrm{Ba}, \mathrm{Cd}, \mathrm{DIC}, \mathrm{Fe}, \mathrm{Mn}, \mathrm{NO}_{3}, \mathrm{PO}_{4}, \\
\mathrm{SiO}_{4}\end{array}$ \\
\hline GIPY05 & $10 / 02 / 2008-16 / 04 / 2008$ & $\mathrm{Al}, \mathrm{Ba}, \mathrm{Cd}, \mathrm{DIC}, \mathrm{Fe}, \mathrm{P}, \mathrm{Si}, \mathrm{TA}, \mathrm{Zn}$ \\
\hline
\end{tabular}




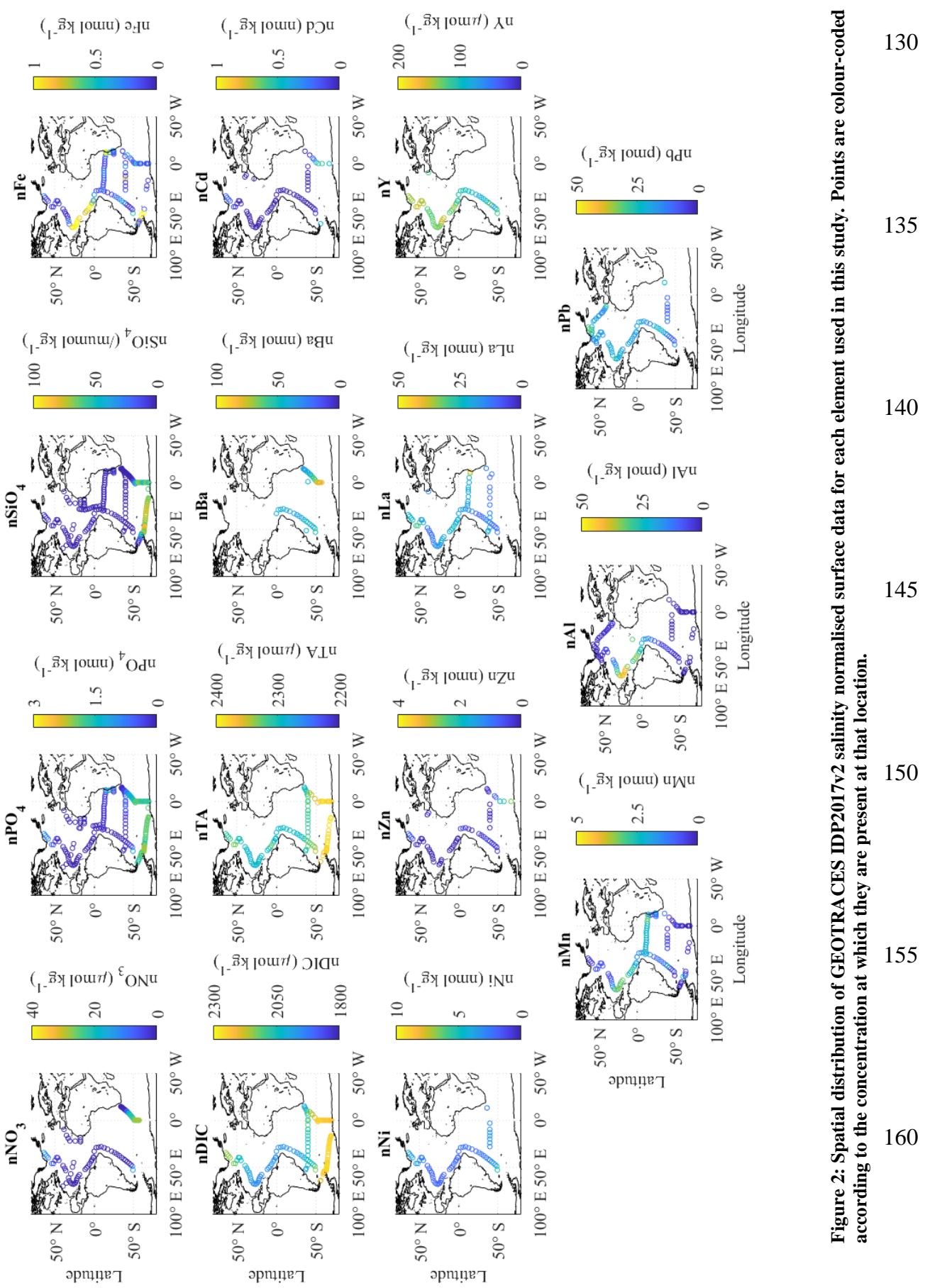


https://doi.org/10.5194/bg-2020-371

Preprint. Discussion started: 19 October 2020

(c) Author(s) 2020. CC BY 4.0 License.

(c) (i)

The GEOTRACES IDP2017v2 was the main dataset used here; however, the GLODAPv2_2019 dataset (more than 700 cruises, 1972 - 2013) (Olsen et al., 2019) was also used (for macronutrients, DIC and TA), to check the validity of the results obtained for

170 the same variables with the smaller GEOTRACES dataset (Sect. 4.1). To compare like with like, only the Atlantic data from GLODAPv2_2019 was used here. Low latitudes are defined in this study as between $30^{\circ} \mathrm{S}$ and $30^{\circ} \mathrm{N}$ and high latitudes as between $50^{\circ}$ and $70^{\circ}$ in the relevant hemisphere. The only elements used in our analysis were those with more than 15 surface layer measurements in both the low and high latitude categories. As shown later (Sect. 4.1), although some of the datasets are relatively small, there is enough data to obtain statistically significant results when testing the hypothesis. However, it is important to note

175 that there are differences between elements in terms of data availability; for instance, there is no high latitude North Atlantic data for $\mathrm{Ba}$ and there is no high latitude South Atlantic data for $\mathrm{La}, \mathrm{Ni}, \mathrm{Pb}$ or Y (Fig. 2).

The data processing followed a similar method to that of Fry et al. (2015) and Wu et al. (2019). The method was applied to both GEOTRACES and GLODAPv2 data. Only bottle data accompanied by a 'good' flag value was used. The surface ocean was

180 defined as $0-20 \mathrm{~m}$ between $30^{\circ} \mathrm{S}$ and $30^{\circ} \mathrm{N}$ and 0-30 m elsewhere. Data from locations with a seafloor depth shallower than 200 $\mathrm{m}$ or salinities less than 33 were excluded so that only open ocean data relatively unaffected by the seafloor and/or rivers is included. Data from the Mediterranean Sea (enclosed basin) was not included. Data from $>65^{\circ} \mathrm{N}$ was excluded so that the heavily freshwater-influenced Arctic Ocean was omitted from the main analysis, although considered separately later (Sect. 4.5).

185 Salinity normalisation was carried out according to:

$X_{n}=\frac{X_{m}}{S} \times 35$

where $S$ is the salinity, $X_{m}$ the measured value, and $X_{n}$ is the salinity-normalised value.

To distinguish between bioutilised and other elements, vertical profiles were plotted from a typical GEOTRACES station at $22^{\circ} \mathrm{S}$, $33^{\circ} \mathrm{W}$ (Fig. 1). On this basis, $\mathrm{Ba}, \mathrm{Cd}, \mathrm{Fe}, \mathrm{Ni}, \mathrm{NO}_{3}, \mathrm{PO}_{4}, \mathrm{SiO}_{4}$ and $\mathrm{Zn}$ are all categorised as bioutilised because their vertical profiles

190 all show surface depletion relative to deep values. Of these elements, all were categorised previously by Broecker and Peng (1982) as bio-limiting or bio-intermediate, except iron and nickel which could not at that time be categorised due to lack of reliable data. $\mathrm{Mn}, \mathrm{La}, \mathrm{Y}$ and $\mathrm{Pb}$, in contrast, do not show surface depletion (Fig. 1) and are categorised here as biounutilised.

Statistical hypothesis testing was carried out using a null hypothesis $\left(H_{0}\right)$ of: "High latitude concentrations are lower than or equal

195 to low latitude concentrations." Most of the element datasets are not normally distributed and so a Mann-Whitney U test was used (one-tailed, assuming equal variances), although similar conclusions (not shown) were obtained when applying a t-test (one-tailed, unequal variances) to the same data.

Spearman's rank order correlation coefficients were calculated between absolute latitude (equivalent, for correlation purposes, to distance from the equator) and concentration of the element. The routine used (the 'corr' function in Matlab) also tested the hypothesis that the two variables are correlated (null hypothesis $\left(H_{0}\right)$ of "no correlation"). All data were included in the correlation calculations, not just the low and high latitude data. 
https://doi.org/10.5194/bg-2020-371

Preprint. Discussion started: 19 October 2020

(c) Author(s) 2020. CC BY 4.0 License.

\section{Results}

All plots and analyses were carried out on salinity-normalised data. In this section, $\mathrm{NO}_{3}$ therefore refers to $\mathrm{nNO}_{3}$, and so on for

other elements.

\subsection{Relationship with latitude}

The geographical distributions of the GEOTRACES data are shown for each element in Fig. 2, with points colour-coded to indicate concentration. The hypothesis can be visually evaluated by inspection of Fig. 2. Figure 3 shows more clearly the presence or absence of a connection with latitude by plotting of data values (concentrations) against latitude.
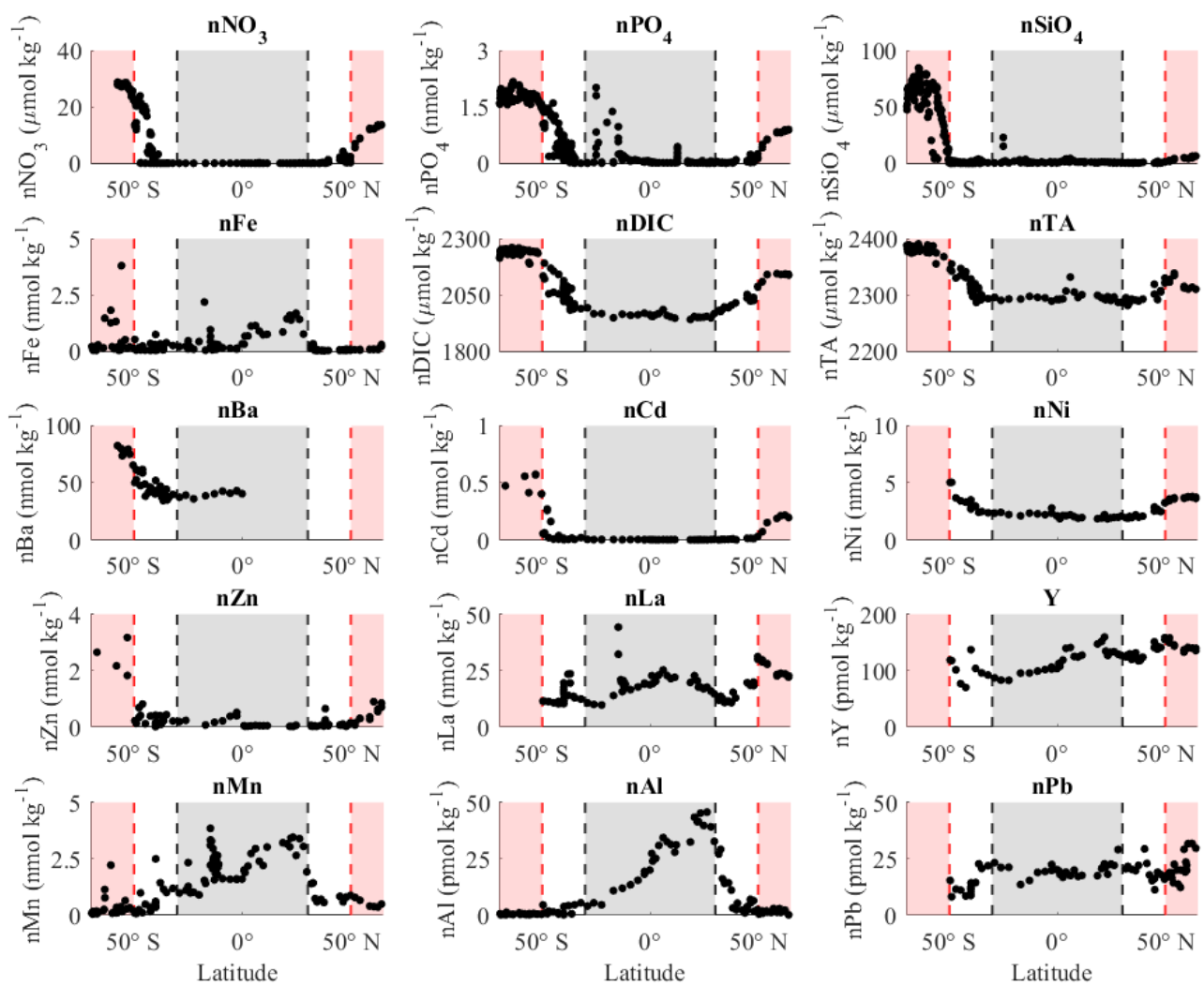

210 Figure 3: Salinity-normalised surface concentrations versus latitude. The grey shaded area (in between the black dotted lines) is the low latitude region $\left(30^{\circ} \mathrm{S}\right.$ to $\left.30^{\circ} \mathrm{N}\right)$; the red shaded areas (polewards of the red dashed lines) are the high latitude regions $\left(50-65^{\circ} \mathrm{N}\right.$ and $\left.<50^{\circ} \mathrm{S}\right)$. Data from GEOTRACES IDP2017v2.

215 Macronutrients: $\mathrm{NO}_{3}, \mathrm{PO}_{4}$ and $\mathrm{SiO}_{4}$ all have their highest concentrations in the Southern Ocean, high values in the high latitude North Atlantic (except $\mathrm{SiO}_{4}$ ) and lowest values in the low latitude Atlantic. 
https://doi.org/10.5194/bg-2020-371

Preprint. Discussion started: 19 October 2020

(C) Author(s) 2020. CC BY 4.0 License.

(c) (i)

DIC and TA: DIC and TA both show maximum concentrations in the Southern Ocean. Additionally, they both show higher concentrations in the high latitude North Atlantic than at lower latitudes (TA less so than DIC). Both show minimum concentrations

220 in the low latitude Atlantic.

Other bioutilised elements: The bioutilised trace elements show varying patterns with latitude. $\mathrm{Ba}, \mathrm{Cd}, \mathrm{Ni}$ and $\mathrm{Zn}$ show highest concentrations in the Southern Ocean and lowest values at low latitudes, in a similar pattern to the macronutrients. In contrast, Fe concentrations are low in the Southern Ocean except for a cluster of values near $60^{\circ} \mathrm{S}$ (near to the tip of the Antarctic peninsula).

225 Additionally, Fe shows high values in the low-latitude North Atlantic and low values in the high latitude North Atlantic.

Biounutilised elements: Mn shows a pattern resembling that of Fe; highest concentrations are seen in the low latitudes, particularly in the North Atlantic west of North Africa, and minimum concentrations in the high latitudes, both north and south.

$\mathrm{Al}$ shows highest concentrations in the mid-latitude North Atlantic. $\mathrm{Pb}$, La and $\mathrm{Y}$ show fairly equal concentrations everywhere,

230 although with somewhat of an increase from furthest south to furthest north.

\subsection{Statistical tests}

Results of the Mann Whitney U test are shown in Table 2, together with mean concentrations for each parameter in the low latitude Atlantic, high latitude North Atlantic and high latitude South Atlantic. The Mann-Whitney U-test found that high latitude concentrations are significantly greater than low latitude concentrations for all of the macronutrients and also DIC, TA, Ba, Ni, Cd, and $\mathrm{Zn}$ (Table 2; for some variables data is not available for both the north and south high-latitude Atlantic). Fe shows a different pattern to the four trace metals just listed. Whilst Fe exhibits a higher mean concentration in the Southern Ocean, this is biased by the cluster of points near to the Antarctic peninsula (values are otherwise low). The low latitude mean for Fe is greater than the high latitude North Atlantic mean. Mn has highest mean concentrations in the low latitude Atlantic and is the only trace metal to have a lower mean concentration in the Southern Ocean than in the high latitude North Atlantic (Table 2). The Mann-Whitney Utest is unable to reject $H_{0}$ for either Fe or Mn (Table 2).

Moving on to consider biounutilised elements, $\mathrm{Al}$ has a low latitude mean that is greater than the high latitude means. $\mathrm{Pb}$ does not have any Southern Ocean data but does have a greater mean in the high latitude North Atlantic compared to low latitudes. Both Y and La have no Southern Ocean data and both have greater mean concentrations in the high latitude North Atlantic than in low

245 latitudes (Table 2). Applying the Mann-Whitney U-test to $\mathrm{Al}, \mathrm{Pb}, \mathrm{Y}$ and La data results in a failure to reject $H_{0}$ for all cases (Table 2).

\subsection{Correlation with proximity to Poles}

Those elements that have significantly higher mean concentrations at high than at low latitudes also tend to have the strongest Spearman rank correlations with latitude (Table 3). DIC, TA, $\mathrm{NO}_{3}, \mathrm{PO}_{4}, \mathrm{Ba}, \mathrm{Cd}$ and $\mathrm{Ni}$ all have strong positive (>+0.6) correlations

250 with latitude. $\mathrm{SiO}_{4}$ and $\mathrm{Zn}$ however show weaker positive correlations with latitude $(+0.16$ and +0.31 respectively $)$ due to an absence of elevated values in the high latitude North Atlantic. Fe and Mn, on the other hand, exhibit negative correlations (-0.26 and -0.71 respectively). Of the biounutilised elements, Al has a strong negative correlation with latitude (-0.76), Y a moderate positive correlation $(+0.44)$ and $\mathrm{Pb}$ and La both have weak correlations (-0.04 and -0.01 respectively). The latter is surprising given that the Mann-Whitney U-test found that high latitude concentrations of La are significantly greater than low latitude concentrations.

255 This discrepancy can be attributed to the Spearman rank correlation being calculated on data from all latitudes in the Atlantic, 
https://doi.org/10.5194/bg-2020-371

Preprint. Discussion started: 19 October 2020

(c) Author(s) 2020. CC BY 4.0 License.

whereas mid-latitude data was not included in the Mann-Whitney U-tests. The null hypothesis of 'no positive correlation' is rejected for all elements except $\mathrm{Pb}, \mathrm{La}, \mathrm{Fe}, \mathrm{Mn}$ and $\mathrm{Al}$.

Table 2: Results of tests (Mann-Whitney U test) of the hypothesis for each element. Tests were carried out on salinity-normalised surface 260 values from the GEOTRACES (top) and GLODAPv2 (bottom) datasets. Those elements exhibiting a significant difference between low latitudes and high latitudes are shown in bold. Rejection of $H_{0}$ at the $5 \%$ level $(\mathrm{p}<0.05)$ is indicated by $\checkmark$, p < 0.01 by $\checkmark \checkmark$, p < 0.001 by $\checkmark \checkmark \checkmark$ and p < 0.0001 by $\checkmark \checkmark \checkmark \checkmark$. ' $x$ ' indicates failure to reject $H_{0}$ even at the $5 \%$ level. LL = low latitude, HL = high latitude, HLN = high latitude north, HLS $=$ high latitude south (all regions are in the Atlantic; boundaries are as defined in Sect. 2). $\overline{\boldsymbol{x}}$ is the average value and $\mathrm{N}$ the number of datapoints for that region.

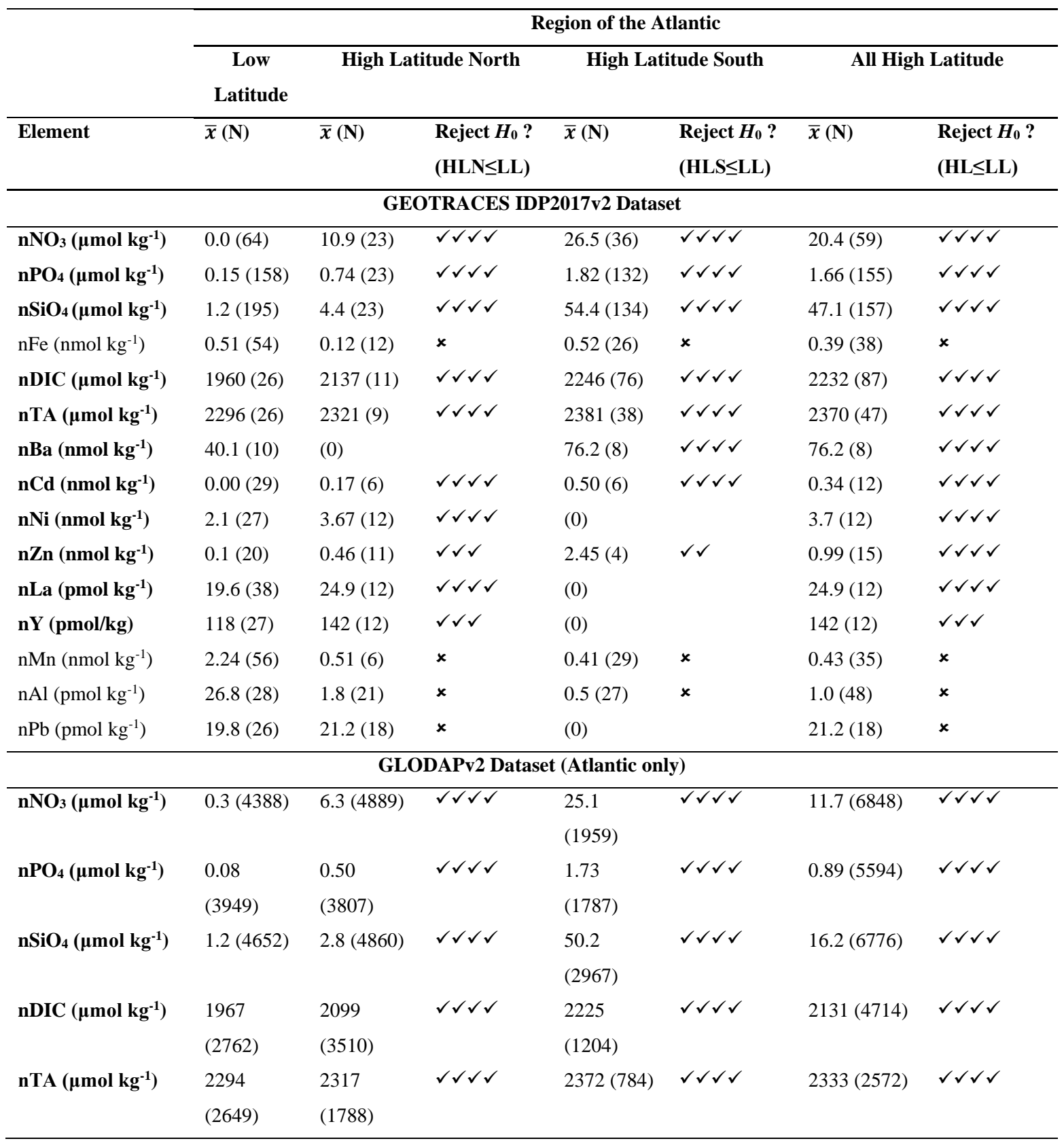


https://doi.org/10.5194/bg-2020-371

Preprint. Discussion started: 19 October 2020

(c) Author(s) 2020. CC BY 4.0 License.

Table 3: Results of correlation analyses for concentration of each element against latitude. Spearman's Rank Correlation Coefficients ( $\rho$ ) were calculated for salinity-normalised surface concentrations from the GEOTRACES dataset against absolute latitude (a measure of distance away from the equator, regardless of which hemisphere). Those elements for which a strong $(\rho>+0.6)$ or very strong $(\rho>+0.8)$ positive correlation was found are highlighted in bold. The final column shows the significance level at which a hypothesis of no positive correlation is rejected ( $\mathrm{p}<0.05$ is indicated by $\checkmark$, p $<0.01$ by $\checkmark \checkmark$, p $<0.001$ by $\checkmark \checkmark \checkmark$ and $\mathrm{p}<0.0001$ by $\checkmark \checkmark \checkmark \checkmark$ ), if it is rejected (' $x$ ' indicates failure to reject even at the $5 \%$ level)

\begin{tabular}{|c|c|c|}
\hline Element & Spearman's $\rho$ & $\begin{array}{c}\text { Reject } \boldsymbol{H}_{0} ? \\
\text { ('no positive correlation') }\end{array}$ \\
\hline \multicolumn{3}{|c|}{ GEOTRACES IDP2017v2 Dataset } \\
\hline $\mathrm{nNO}_{3}$ & 0.85 & $\checkmark \checkmark \checkmark \checkmark$ \\
\hline $\mathrm{nPO}_{4}$ & 0.80 & $\checkmark \checkmark \checkmark \checkmark$ \\
\hline $\mathrm{nSiO}_{4}$ & 0.45 & $\checkmark \checkmark \checkmark \checkmark$ \\
\hline $\mathrm{nFe}$ & -0.26 & $x$ \\
\hline nDIC & 0.91 & $\checkmark \checkmark \checkmark \checkmark$ \\
\hline nTA & $\mathbf{0 . 8 3}$ & $\checkmark \checkmark \checkmark \checkmark$ \\
\hline $\mathbf{n B a}$ & 0.76 & $\checkmark \checkmark \checkmark \checkmark$ \\
\hline nCd & 0.87 & $\checkmark \checkmark \checkmark \checkmark$ \\
\hline $\mathrm{nNi}$ & 0.78 & $\checkmark \checkmark \checkmark \checkmark$ \\
\hline $\mathrm{nZn}$ & 0.51 & $\checkmark \checkmark \checkmark \checkmark$ \\
\hline $\mathrm{nLa}$ & -0.01 & $x$ \\
\hline nY & 0.44 & $\checkmark \checkmark \checkmark$ \\
\hline $\mathrm{nMn}$ & -0.78 & $x$ \\
\hline $\mathrm{nAl}$ & -0.76 & $x$ \\
\hline $\mathrm{nPb}$ & -0.04 & $x$ \\
\hline \multicolumn{3}{|c|}{ GLODAPv2 Dataset (Atlantic only) } \\
\hline $\mathrm{nNO}_{3}$ & 0.76 & $\checkmark \checkmark \checkmark \checkmark$ \\
\hline $\mathrm{nPO}_{4}$ & 0.75 & $\checkmark \checkmark \checkmark \checkmark$ \\
\hline $\mathrm{nSiO}_{4}$ & 0.43 & $\checkmark \checkmark \checkmark \checkmark$ \\
\hline nDIC & 0.84 & $\checkmark \checkmark \checkmark \checkmark$ \\
\hline nTA & 0.66 & $\checkmark \checkmark \checkmark \checkmark$ \\
\hline
\end{tabular}

\section{Discussion}

\subsection{Is there enough data to test the hypothesis?}

275 The GEOTRACES IDP2017v2 dataset consists of a smaller number of cruises in the Atlantic (13) than does GLODAPv2_2019 (247). In addition, for some variables ( $\mathrm{Ba}, \mathrm{Ni}, \mathrm{La}, \mathrm{Y}, \mathrm{Pb}$ ), there is high-latitude data from only one hemisphere rather than from both. We now consider whether there is sufficient data in GEOTRACES to carry out a meaningful examination of the hypothesis.

This question can first be examined by comparing results from GEOTRACES to those from the larger GLODAPv2 dataset. As 280 can be seen in Fig. 4, distributions of the same elements within the two datasets are similar and the major relationships with latitude are apparent in both. From this it can be concluded that there is enough data in the smaller GEOTRACES dataset to pick out the 
https://doi.org/10.5194/bg-2020-371

Preprint. Discussion started: 19 October 2020

(c) Author(s) 2020. CC BY 4.0 License.

main trends in the data, even though one or two differences are observed between the two datasets. Most noticeably, $\mathrm{PO}_{4}$ values are elevated (as high as $2 \mu \mathrm{mol} \mathrm{kg}{ }^{-1}$ ) at $25^{\circ} \mathrm{S}$ in GEOTRACES but not to the same degree in GLODAPv2 (Fig. 4). The elevated values are from samples taken in the Benguela upwelling region (Fig. 1). Although GLODAPv2 cruises also sampled there, GEOTRACES sampling may have coincided with a time of intense upwelling whereas GLODAPv2 sampling did not. It seems, therefore, that details in the data patterns are sensitive to the particular times and places of sampling but that the main trends in the data are not.

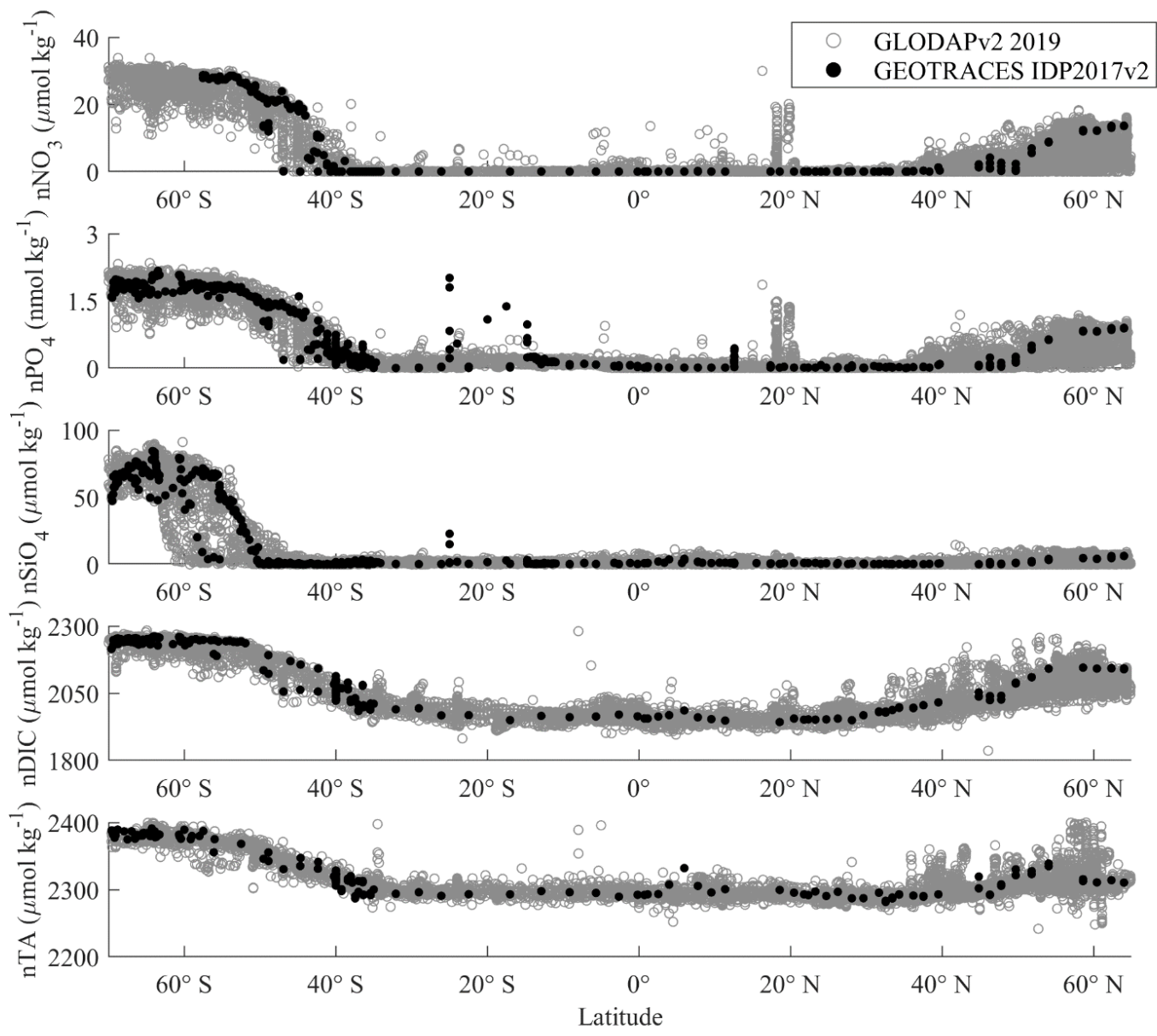

290 Figure 4: Comparison of latitudinal distributions of salinity-normalised surface concentrations of $\mathrm{PO}_{4}, \mathrm{NO}_{3}$, $\mathrm{SiO}_{4}$, $\mathrm{TA}_{\mathrm{and}} \mathrm{DIC}$. Data from GLODAPv2 is shown with grey circles and data from GEOTRACES IDP2017v2 with black circles.

Most results are significant not only at the $5 \%$ but also at the $1 \%$ and the $0.1 \%$ levels (Tables 2 and 3 ). In other words, it is surpassingly unlikely in most cases that the differences between low latitude and high latitude means are just down to chance variations in small datasets. In addition, if there is no real trend towards higher values at higher latitudes then we would not expect 
https://doi.org/10.5194/bg-2020-371

Preprint. Discussion started: 19 October 2020

(C) Author(s) 2020. CC BY 4.0 License.

(c) (i)

correlations between absolute latitude and element concentration. Again, the results obtained are very clear: most elements are highly correlated $(\rho>0.6)$ with absolute latitude and, in addition, a hypothesis of no correlation is strongly rejected.

\subsection{Outcomes}

300 4.2.1 Outcome 1 of tests: Most bioutilised elements do increase with latitude

All of the macronutrients as well as DIC and TA have higher concentrations at high latitudes. Other bioutilised elements measured by GEOTRACES (specifically barium, cadmium, nickel and zinc) also share the same pattern (Table 2).

\subsubsection{Outcome 2 of tests: Not all bioutilised elements increase with latitude}

However, one bioutilised element does not share the behaviour: (i) a plot of Fe against latitude does not show increasing values

305 towards high latitudes; (ii) there is no strong correlation with absolute latitude; (iii) statistical hypothesis testing is unable to reject either the hypothesis of "high latitude concentrations $\leq$ low latitude concentrations" or the hypothesis of "no correlation between concentration and absolute latitude". We do not attempt to find a definitive answer here to the question of why Fe and Mn do not share the same pattern. However, it seems likely that Fe does not share the pattern because it is the proximate limiting nutrient in regions of upwelling / strong winter mixing (Moore et al., 2016) (including most high-latitude regions) and as a result is depleted

310 to near-exhaustion in those surface waters (particularly in summer, when most ship-based observations are made at high latitudes).

\subsubsection{Outcome 3 of tests: biounutilised elements do not increase with latitude}

Plankton in general are not known to have any requirements for La, Y, Al or Pb (Frausto da Silva and Williams, 2001) although Al may be used in the siliceous frustules of diatoms (Gehlen et al., 2002). These elements were also tested to see if they exhibited a general pattern of higher values at high latitudes, but none did. Plots of values against latitude did not show elevation at high

315 latitudes. Although yttrium exhibits a northwards increase along the Atlantic from lowest values at $\sim 50^{\circ} \mathrm{S}$ to highest values at $\sim 60^{\circ} \mathrm{N}$, yttrium values do not increase away from the equator in both directions. For $\mathrm{La}, \mathrm{Al}$ and $\mathrm{Pb}$, hypothesis testing was unable to reject the null hypotheses above and correlation analyses did not find any strong positive correlations with absolute latitude.

\subsection{Probable physical cause of the enrichment of bioutilised elements at high latitudes}

The phenomenon of high latitude enrichment has been shown here to hold true for all bioutilised elements examined except Fe. We now speculate as to the most likely cause of this phenomenon.

Deep waters have higher concentrations of most bioutilised elements through the actions of the biological pump (Fig. 1). Therefore, when deep water is introduced into the surface layer it usually produces an increase in the concentrations there. However, deep waters are not often brought to the surface at low latitudes, because of the strong temperature differential between warm surface waters and cold deep waters. Deep waters are uniformly cold: $\left(4-15{ }^{\circ} \mathrm{C}\right.$ below $500 \mathrm{~m}$, according to GLODAPv2 data) whereas surface waters between $30^{\circ} \mathrm{S}$ and $30^{\circ} \mathrm{N}$ are uniformly warm $\left(15-27^{\circ} \mathrm{C}\right.$ above $\left.100 \mathrm{~m}\right)$. The density of seawater is strongly affected by its temperature, with warm water less dense than cold water. Although wind driven upwelling does occur at low latitudes (Kämpf and Chapman, 2016), such upwelling comes from relatively shallow depths (e.g. < $300 \mathrm{~m}$ ) rather than from very deep in the ocean. Water from these intermediate depths is not so cold (e.g. $10-25^{\circ} \mathrm{C}$ between 100 and $300 \mathrm{~m}$ ) and is therefore able to be 330 brought to the surface. 
In short, the overall thermal structure of the ocean (Fig. 5) inhibits water rising from considerable depth to the surface at low latitudes but, in contrast, permits it to do so at high latitudes.

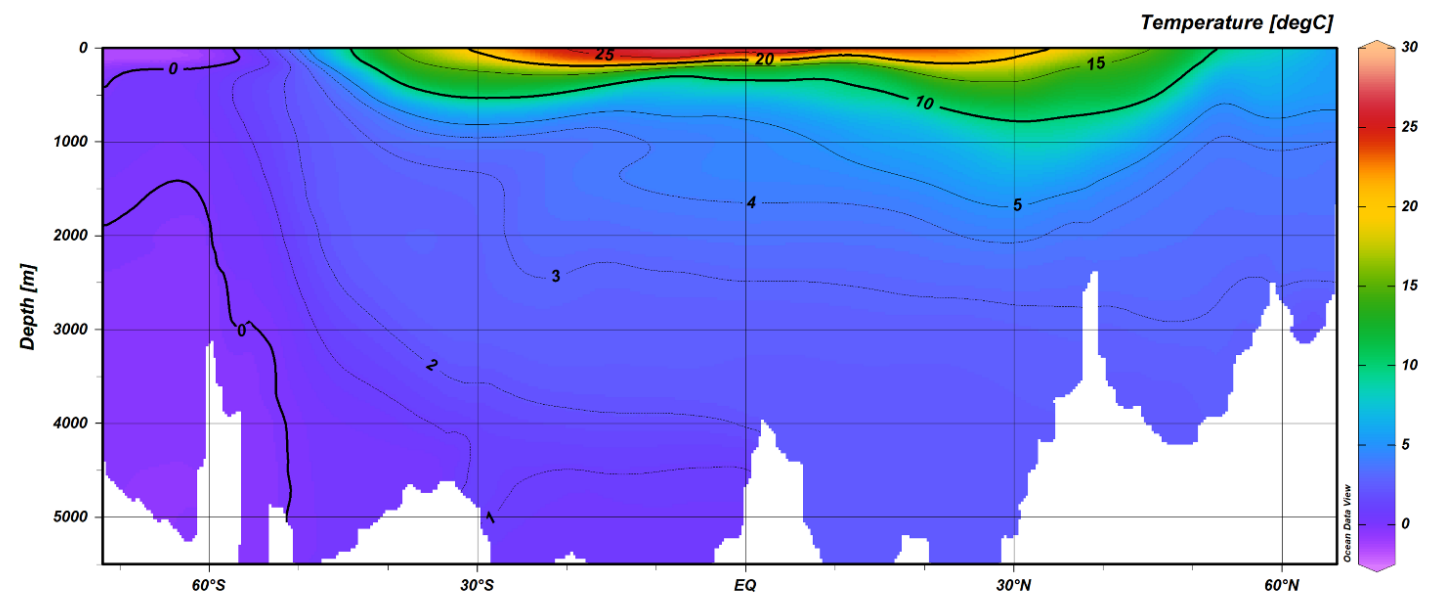

335 Figure 5: Vertical section of temperature versus latitude in the Atlantic. Data source (average of all data from between $40-20^{\circ} \mathrm{W}$ and 1955 - 2012) : World Ocean Atlas 2013, plotted with Ocean Data View (Schlitzer, 2018).

We now consider the physics of the Atlantic Ocean in particular. Upwelling in the Atlantic sector of the Southern Ocean is of Circumpolar Deep Water (CDW) from about $1000 \mathrm{~m}$ depth. Because of the long time since that water left the surface, it contains

340 large quantities of the products of organic matter remineralisation. There is little or no upwelling in the high latitude North Atlantic but there is deep winter mixing (to depths of $740 \mathrm{~m}$ in Greenland Sea and $550 \mathrm{~m}$ in Labrador Sea (de Boyer Montegut et al., 2004)). However, the water that is entrained in autumn and winter into the deepening surface layer is water that has only relatively recently left the surface (because the high-latitude North Atlantic is a deep water formation region, at the beginning of the deep ocean conveyor). The deep water that is stirred up into the surface of the high latitude North Atlantic is not greatly enriched in elements

345 because it is 'young' deep water that has not had time to accumulate the products of particle flux remineralisation to any great extent; for this reason, the degree of enrichment of surface waters in the high-latitude North Atlantic is not as great as in the Southern Ocean. This can be seen in the results of our analyses. Of those elements which exhibit high latitude enrichment, the enrichment in the high latitude South Atlantic (Southern Ocean) is always greater than that in the high latitude North Atlantic, without exception (Table 2). There is some enrichment in the high latitude North Atlantic, but it is less intense than in the Southern

350 Ocean.

\subsection{Input of deep water is not the only process}

While it is argued here that there is a general tendency towards increased concentrations of bioutilised elements at high latitudes because of deep water inputs, we do not suggest that this is the only process affecting latitudinal patterns in elemental concentrations. For instance, an excess of evaporation over precipitation in the subtropical gyres tends to raise concentrations of elements there (i.e. at lower latitudes), opposing the pattern described here. This is seen for instance in TA before salinity normalisation. As described above, biological uptake of the most limiting nutrient until it is exhausted overrides the tendency for iron to have higher concentrations at high latitudes. Higher concentrations of DIC at high latitudes are known to be in large part due to solubility variations with temperature, as well as the effects of upwelling (Wu et al., 2019). 
https://doi.org/10.5194/bg-2020-371

Preprint. Discussion started: 19 October 2020

(C) Author(s) 2020. CC BY 4.0 License.

(c) (i)

\subsection{Arctic counter-example}

360 Data from the Arctic Ocean $\left(>65^{\circ} \mathrm{N}\right)$ has not been included in this study. However, previous studies have reported generally low levels of macronutrients, DIC and total alkalinity in the surface waters of the western basin of the Arctic Ocean (e.g. Codispoti et al., 2005; Woosley and Millero, 2020), contrary to the general pattern shown here. It is clear that the western Arctic Ocean does not follow the rule of high-latitude enrichment.

365 We presume that the reason why the Arctic does not follow the general pattern is that large volumes of river water enter the Arctic Ocean each year. Because of this, surface waters in the Arctic are considerably less saline (30-33.5; (Swift et al. 1997)) than deep waters (34.93-34.95; (Aagaard, 1981; Jones et al., 1995)). There is a strong halocline across the whole of the Arctic basin (Aagaard et al., 1981). So, although there is not a strong vertical temperature gradient in the Arctic, there is a strong vertical salinity gradient. Salinity also influences the density of seawater (more saline waters are more dense). For this reason the exchange of surface and

370 deep waters is impeded in the Arctic by salinity difference rather than temperature difference, and it is this that prevents supply of elements from below, allowing concentrations to stay low at the surface (Codispoti et al., 2005; Reigstad et al., 2002; Jensen et al., 2019). Because of buoyancy of surface waters due to low salinity, the physical mechanism that increases concentrations in most high-latitude oceans cannot operate in the Arctic Ocean.

\subsection{Relationship to previous work}

375 Much previous work on trace element distributions has focussed on understanding vertical patterns (Bruland et al., 2014) and similarities between vertical distributions of different elements, for instance Cd and P (de Baar et al., 1994; Middag et al., 2018) and $\mathrm{Zn}$ and Si (Vance et al., 2017; Middag et al., 2019). This paper investigates instead horizontal distributions.

Other work has, like us, investigated controls on horizontal surface distributions of different elements. Many studies have identified

380 a pattern of high dissolved Fe concentrations above shelves and close to shore, because of Fe release from sediments (e.g. Johnson et al., 1997). Continental shelves and margins are an important source of other elements as well, including Mn (Laës et al., 2007) and Co (Tagliabue et al., 2018). Inputs of Saharan dust are responsible for the higher dissolved $\mathrm{Fe}$ (and $\mathrm{Al}$ and $\mathrm{Mn}$ ) concentrations in the subtropical North Atlantic, leading, indirectly, to lower $\mathrm{PO}_{4}$ concentrations in the subtropical North Atlantic than in the subtropical South Atlantic (Mather et al., 2008). Rare earth elements (REE) have been found to increase towards coastal and high

385 latitude regions in the North Pacific (Hongo et al., 2006). Other known drivers of surface distributions include Fe from volcanic ash (Duggen et al., 2010), temperature for DIC and river inputs near the mouths of large rivers (Cooley and Yager, 2006). Although there is clearly a great variety of controls, the results presented here point to the existence of one common driver that is important for all bioutilised elements except iron: deep water exchange at high latitudes exerts a strong influence over the horizontal distributions of them all.

\section{4.7. Predictions}

Based on our results from the Atlantic and for a limited number of elements, we make the following testable predictions:

(1) That other bioutilised elements (ones not measured on GEOTRACES cruises - for instance $\mathrm{Ca}$ and $\mathrm{Ge}$ ) will be found to exhibit the same pattern.

(2) That the patterns found in the Atlantic will also be found in the Pacific. 
https://doi.org/10.5194/bg-2020-371

Preprint. Discussion started: 19 October 2020

(C) Author(s) 2020. CC BY 4.0 License.

(c) (i)

(3) That the degree of enrichment in the high-latitude North Pacific will be greater than that in the high-latitude North Atlantic (because the deep waters there, at the end of the deep ocean conveyor, have higher concentrations).

(4) That bioutilised elements not yet measured in the western Arctic will be found to occur at low concentrations.

\section{Conclusions}

The main finding of this study is a general principle that elements taken up by biology tend to be more abundant in high-latitude surface waters than in low-latitude surface waters. The reason is that element-rich deep water is able to rise to the surface at high latitudes because surface waters there have similar temperatures to deep waters. In other words, the vertical pattern induces a horizontal pattern: the increase in elemental concentrations with depth promotes an increase in concentrations with latitude. Iron is found to be an exception to the rule, presumably because of its role as the limiting nutrient for primary production in upwelling regions. Moreover, Arctic surface waters are not enriched - this is explained by the Arctic halocline which prevents exchange of 405 surface and deep waters.

Data availability. Data for this study came from the GEOTRACES Intermediate Data Product 2017 version 2 (GEOTRACES IDP2017, Schizter et al., 2018) and the Global Ocean Data Analysis Project version 2 (GLODAPv2_2019, Olsen et al., 2016; 2019, Key et al., 2015). Both data products are publicly available, GEOTRACES at: https://www.geotraces.org/geotracesintermediate-data-product-2017/ and GLODAP at: https://www.glodap.info/index.php/merged-and-adjusted-data-product-v2-

410 2019/.

Author Contributions. TT was responsible for the initial idea that formed the basis of this research. DP carried out data acquisition, analysis, and investigation with supervision from TT. The manuscript was drafted by both DP and TT with review and editing contributions made equally.

Competing Interests. The authors declare that they have no conflicts of interest.

415 Acknowledgments. We thank the many scientists involved in GEOTRACES cruises and data collection, as well as those who contributed to data product compilation. Additionally, we extend thanks to Professor Maeve Lohan for providing information about the GEOTRACES data. We would also like to thank the GLODAPv2_2019 team for the composition of the data product and data originators for their contributions.

\section{References}

420 Aagaard, K.: On the deep circulation in the Arctic Ocean, Deep-Sea Res., 28, 251-268, doi:10.1016/0198-0149(81)90066-2, 1981. Aagaard, K., Coachman, L. K., and Carmack, E.: On the halocline of the Arctic Ocean, Deep Sea Res., 28, 529-545, doi:10.1016/0198-0149(81)90115-1, 1981.

Azam, F., and Volcani, B. E.: Germanium-Silicon Interactions in Biological Systems, in: Silicon and Siliceous Structures in Biological Systems, edited by: Simpson, T. L., and Volcani B. E., Springer, New York, NY, 1981. 
https://doi.org/10.5194/bg-2020-371

Preprint. Discussion started: 19 October 2020

(c) Author(s) 2020. CC BY 4.0 License.

(c) (i)

425 Boyd, P. W., Jickells, T., Law, C. S., Blain, S., Boyle, E. A., Buesseler, K. O., Coale, K. H., Cullen, J. J., De Baar, H. J. W., Follows, M., Harvey, M., Lancelont, C., Levasseur, M., Owens, N. P. J., Pollard, R., Rivkin, R. B., Sarmiento, J., Schoemann, V., Smetacek, V., Takeda, S., Tsuda, A., Turner, S., and Watson, A. J.: Mesoscale iron enrichment experiments 1993-2005: synthesis and future directions, Science, 315, 612-617, doi:10.1126/science.1131669, 2007.

Brewer, P. G., Takahashi, T., and Williams, R. T.: Transient Tracers in the Oceans (TTO) - hydrographic data and carbon dioxide systems with revised carbon chemistry data, Carbon Dioxide Information Center, U.S. Department of Energy, Oak Ridge, Tennessee, 1986.

Broecker, W. S., and Peng, T. H.: Tracers in the sea, Lamont-Doherty Geological Observatory, Columbia University, Palisades, NY, 1982.

Bruland, K. W., Middag, R., and Lohan, M. C.: 8.2 - Controls of Trace Metals in Seawater, in: Treatise on Geochemistry (Second

435 Edition), edited by: Holland, H. D., and Turekian, H. D., Elsevier, 19-51, doi:10.1016/B978-0-08-095975-7.00602-1, 2014.

Carter, B.R., Toggweiler, J.R., Key, R.M., and Sarmiento, J.L.: Processes determining the marine alkalinity and calcium carbonate saturation state distributions, Biogeosciences, 11, 7349-7362, doi:10.5194/bg-11-7349-2014, 2014.

Chapman, P.: The World Ocean Circulation Experiment (WOCE), Mar. Technol. Soc. J., 32, 23-36, 1998.

Codispoti, L. A., Flagg, C., Kelly, V., and Swift, J. H.: Hydrographic conditions during the 2002 SBI process experiments, Deep-

440 Sea Res. Pt. II, 52, 3199-3226, doi:10.1016/j.dsr2.2005.10.007, 2005.

Conkright, M.E., Gregg, W.W., and Levitus, S.: Seasonal cycle of phosphate in the open ocean, Deep-Sea Res. Pt I, 47, 159-175, doi:10.1016/S0967-0637(99)00042-4, 2000.

Cooley, S. R., and Yager, P. L.: Physical and biological contributions to the western tropical North Atlantic Ocean carbon sink formed by the Amazon River plume, J. Geophys. Res., 111, doi:10.1029/2005JC002954, 2006.

445 de Baar, H. J. W., Boyd, P. W., Coale, K. H., Landry, M. R., Tsuda, A., Assmy, P., Bakker, D. C. E., Bozec, Y., Barber, R. T., Brzezinski, M.A., Buesseler, K.O., Boye, M., Croot, P. L., Gervais, F., Gorbunov, M. Y., Harrison, P. J., Hiscock, W. T., Laan, P., Lancelot, C., Law, C. S., Levasseur, M., Marchetti, A., Millero, F. J., Nishioka, J., Nojiri, Y., van Oijen, T., Riebesell, U., Rijkenberg, M. J. A., Saito, H., Takeda, S., Timmermans, K. R., Veldhuis, M. J. W., Waite, A. M., and Wong, C.:. Synthesis of iron fertilization experiments: from the iron age in the age of enlightenment, J. Geophys. Res.-Oceans, 110, 450 doi:10.1029/2004JC002601, 2005.

de Baar, H. J. W., Saager, P. M., Nolting, R. F., and van der Meer, J.: Cadmium versus phosphate in the world ocean, Mar. Chem., 46, 261-281, doi:10.1016/0304-4203(94)90082-5, 1994.

de Boyer Montégut, C., Madec, G., Fischer, A. S., Lazar, A., and Ludicone, D.: Mixed layer depth over the global ocean: An examination of profile data and a profile-based climatology, J. Geophys. Res., 109, https://doi.org/10.1029/2004JC002378, 2004.

Duggen, S., Olgun, N., Croot, P., Hoffmann, L., Dietze, H., Delmelle, P., and Teschner, C.: The role of airborne volcanic ash for the surface ocean biogeochemical iron-cycle: a review, Biogeosciences, 7, 827-844, doi:10.5194/bg-7-827-2010, 2010.

Frausto da Silva, J. J. R., and Williams, R. J. P.: The Biological Chemistry Of Elements (Second Edition), Oxford University Press, Oxford, 2001.

Friis, K., Körtzinger, A., and Wallace, D. W. R.: The salinity normalization of marine inorganic carbon chemistry data, Geophys.

Fry, C. H., Tyrrell, T., Hain, M. P, Bates, N. R., and Achterberg, E. P.: Analysis of global surface ocean alkalinity to determine controlling processes, Mar. Chem., 174, 46-57, doi:10.1016/j.marchem.2015.05.003, 2015. 
https://doi.org/10.5194/bg-2020-371

Preprint. Discussion started: 19 October 2020

(C) Author(s) 2020. CC BY 4.0 License.

(c) (i)

Gehlen, M., Beck, L., Calas, G., Flank, A. M., Van Bennekom, A. J., and Van Beusekom, J. E. E.: Unraveling the atomic structure of biogenic silica: evidence of the structural association of $\mathrm{Al}$ and $\mathrm{Si}$ in diatom frustules, Geochim. Cosmochim. Ac., 66, 1601-

465 1609, doi:10.1016/S0016-7037(01)00877-8, 2002.

Gordon, L. I., Jennings Jr., J. C., Ross, A. A., and Krest, J. M.: A suggested protocol for continuous flow automated analysis of seawater nutrients (phosphate, nitrate, nitrite and silicic acid) in the WOCE Hydrographic Program and the Joint Global Ocean Fluxes Study, Methods Manual WHPO, 91-1, 1993.

Hongo, Y., Obata, H., Sotto Alibo, D., and Nozaki, Y.: Spatial variations of rare earth elements in north pacific surface water, J.

470 Oceanogr., 62, 441-455, doi:10.1007/s10872-006-0067-1, 2006.

Jensen, L. T., Wyatt, N. J., Twining, B. S., Rauschenberg, S., Landing, W. M., Sherrell, R. M., and Fitzsimmons, J. N.: Biogeochemical Cycling of Dissolved Zinc in the Western Arctic (Arctic GEOTRACES GN01), Global Biogeochem. Cy., 33, 343-369, doi:10.1029/2018GB005975, 2019.

Jiang, Z. P., Tyrrell, T., Hydes, D. J., Dai, M., and Hartman, S. E.: Variability of alkalinity and the alkalinity-salinity relationship

in the tropical and subtropical surface ocean, Global Biogeochem. Cy., 28, 729-742, https://doi.org/10.1002/2013GB004678, 2014.

Jones, E.P., Rudels, B., and Anderson, L. G.: Deep waters of the Arctic Ocean: origins and circulation, Deep-Sea Res. Pt. I, 42, doi:10.1016/0967-0637(95)0013-V, 1995.

Kämpf, J. and Chapman, P.: Upwelling systems of the world, Springer International Publishing, Switzerland, 31-42, 2016.

Key, R. M., Kozyr, A., Sabine, C. L., Lee, K., Wanninkhof, R., Bullister, J. L., Feely, R. A., Millero, F. J., Mordy, C., and Peng,

480 T. H.: A global ocean carbon climatology: Results from Global Data Analysis Project (GLODAP), Global Biogeochem. Cy., 18, GB4031, https://doi.org/10.1029/2004GB002247, 2004.

Key, R. M., Olsen, A., van Heuven, S., Lauvset, S. K., Velo, A., Lin, X., Schirnick, C., Kozyr, A., Tanhua, T., and Hoppema, M.:

Global Ocean Data Analysis Project, Version 2 (GLODAPv2), ORNL/CDIAC-162, NDP093, https://doi.org/10.3334/CDIAC/OTG.NDP093_GLODAPv2, 2015.

485 Laës, A., Blain, S., Laan, P., Ussher, S. J., Achterberg, E. P., Tréguer, P., and de Baar, H. J. W.: Sources and transport of dissolved iron and manganese along the continental margin of the Bay of Biscay, Biogeosciences, 4, 181-194, doi:10.5194/bg-4-181-2007, 2007.

Lee, K., Wanninkhof, R., Feely, R. A., Millero, F. J., and Peng, T. H.: Global relationships of total inorganic carbon with temperature and nitrate in surface seawater, Global Biogeochem. Cy., 14, 979-994, https://doi.org/10.1029/1998gb001087, 2000.

490 Lee, K., Tong, L. T., Millero, F. J., Sabine, C. L., Dickson, A. G., Goyet, C., Park, G., Wanninkhof, R., Feely, R. A., and Key, R. M.: Global relationships of total alkalinity with salinity and temperature in surface waters of the world's oceans, Geophys. Res. Lett., 33, doi:10.1029/2006GL027207, 2006.

Levitus, S., Conkright, M. E., Reid, J. L., Najjar, R. G., and Mantyla, A.: Distribution of nitrate, phosphate and silicate in the world oceans, Prog. in Oceanogr., 31, 245-273, doi:10.1016/0079-6611(93)90003-V, 1993.

495 Martiny, A., Lomas, M., Fu, W., Boyd, P., Chen, Y., Cutter, G., Ellwood, M., Furuya, K., Hashihama, F., Kanda, J., Karl, D., Kodama, T., Li, Q., Ma, J., Moutin, T., Woodward, E., J.K. Moore, J.: Biogeochemical controls of surface ocean phosphate, Sci. Adv., 5, doi:10.1126/sciadv.aax0341, 2019.

Mather, R.L., Reynolds, S.E., Wolff, G.A., Williams, R.G., Torres-Valdes, S., Woodward, E.M.S., Landolfi, A., Pan, X., Sanders, R. and Achterberg, E.P.: Phosphorus cycling in the North and South Atlantic Ocean subtropical gyres. Nat. Geosci., 1, 439-443. 
https://doi.org/10.5194/bg-2020-371

Preprint. Discussion started: 19 October 2020

(C) Author(s) 2020. CC BY 4.0 License.

Middag, R., de Baar, H. J. W., and Bruland, K. W.: The Relationships Between Dissolved Zinc and Major Nutrients Phosphate and Silicate Along the GEOTRACES GA02 Transect in the West Atlantic Ocean, Global Biogeochem. Cy., 33, 63-84, doi:10.1029/2018GB006034, 2019.

Middag, R., de Baar H. J. W., Bruland K. W., and van Heuven S. M. A. C.: The Distribution of Nickel in the West-Atlantic Ocean, Its Relationship With Phosphate and a Comparison to Cadmium and Zinc, Frontiers in Marine Science, 7, doi:10.3389/fmars.2020.00105, 2020.

Middag, R., van Heuven, S. M. A. C., Bruland, K. W., and de Baar, H. J. W.: The relationship between cadmium and phosphate in the Atlantic Ocean unravelled, Earth Planet. Sc. Lett., 492, 79-88, https://doi.org/10.1016/j.eps1.2018.03.046, 2018.

Millero, F. J., Lee, K., and Roche, M.: Distribution of alkalinity in the surface waters of the major oceans, Mar. Chem., 60, 111-

510 130, doi:10.1016/S0304-4203(97)00084-4, 1998.

Moore, C. M.: Diagnosing oceanic nutrient deficiency, Philos. T. R. Soc. A, 374, https://doi.org/10.1098/rsta.2015.0290, 2016.

Moore, W. S.: "Review of the GEOSECS project", Nucl. Instrum. and Methods Phys, Res., 223, doi:10.1016/0167-5087(84)906926, 459-465, 1984.

Olsen, A., Key, R. M., van Heuven, S., Lauvset, S. K., Velo, A., Lin, X., Schirnick, C., Kozyr, A., Tanhua, T., Hoppema, M.,

515 Jutterström, S., Steinfeldt, R., Jeansson, E., Ishii, M., Pérez, F. F., and Suzuki, T.: The Global Ocean Data Analysis Project version 2 (GLODAPv2) - an internally consistent data product for the world ocean, Earth Syst. Sci. Data, 8, 297-323, doi:10.5194/essd8-297-2016, 2016.

Olsen, A., Lange, N., Key, R. M., Tanhua, T., Álvarez, M., Becker, S. M., Bittig, H. C., Carter, B. R., Cotrim da Cunha, L., Feely, R., van Heuven, S., Hoppema, M., Ishii, M., Jeansson, E., Jones, S., Jutterström, S., Karlsen, M. K., Kozyr, A., Lauvset, S., Lo

520 Monaco, C., Murata, A., Pérez, F. F., Pfeil, B., Schirnick, C., Steinfeldt, R., Suzuki, T., Telszewski, M., Tilbrook, B., Velo, A., and Wanninkhof, R.: GLODAPv2.2019 - an update of GLODAPv2, Earth Syst. Sci. Data, 11, 1437-1461, doi:10.5194/essd-111437-2019, 2019

Raven, J. A.: Predictions of Mn and Fe use efficiencies of phototrophic growth as a function of light availability for growth and of C assimilation pathway, New Phytol., 116, 1-18, doi:10.1111/j.1469-8137.1990.tb00505.x, 1990.

525 Reigstad, M., Wassmann, P., Wexels Riser, C., Øygarden, S., and Rey, F.: Variation in hydrography, nutrients and chlorophyll a in the marginal ice zone and the central Barents Sea, J. Marine Syst., 38, 9-29, doi:10.1016/S0924-7963(02)00167-7, 2002.

Sarmiento, J. L., and Gruber, N.: Ocean biogeochemical dynamics, Princeton University Press, USA, 2006.

Schlitzer, R.: Ocean Data View, https://odv.awi.de, 2018.

Schlitzer, R., Anderson, R. F., Dodas, E. M., Lohan, M., and Geibert, W.: The GEOTRACES Intermediate Data Product 2017,

530 Chem. Geol., 493, 210-223, doi:10.1016/j.chemgeo.2018.05.040, 2018.

Strickland, J. D. H., and Parsons, T.: A Practical Handbook Of Seawater Analysis (Second Edition), Fisheries Research Board of Canada, Canada, 1972.

Swift, J. H., Jones, E. P., Aagaard, K., Carmack, E. C., Hingston, M., MacDonald, R. W., McLaughlin, F. A., and Perkin, R.G.: Waters of the Makarov and Canada basins, Deep-Sea Res. Pt. II, 44, 1503-1529, doi:10.1016/S0967-0645(97)00055-6, 1997.

535 Tagliabue, A., Hawco, N.J., Bundy, R.M., Landing, W.M., Milne, A., Morton, P.L. and Saito, M.A.: The role of external inputs and internal cycling in shaping the global ocean cobalt distribution: insights from the first cobalt biogeochemical model, Global Biogeochem. Cy., 32, 594-616, 2018.

Takahashi, T., Olafsson, J., Goddard, J. G., Chipman, D. W., and Sutherland, S. C.: Seasonal variation of CO2 and nutrients in the high - latitude surface oceans: A comparative study, Global Biogeochem. Cycles, 7, 843- 878, doi:10.1029/93GB02263, 1993. 
https://doi.org/10.5194/bg-2020-371

Preprint. Discussion started: 19 October 2020

(c) Author(s) 2020. CC BY 4.0 License.

(c) (1)

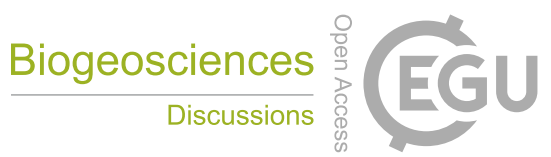

540 Takahashi, T., Sutherland, S. C., Chipman, D. W., Goddard, J. G., Ho, C., Newberger, T., Sweeney, C., and Munro, D. R.: Climatological distributions of $\mathrm{pH}, \mathrm{pCO} 2$, total $\mathrm{CO} 2$, alkalinity, and $\mathrm{CaCO} 3$ saturation in the global surface ocean, and temporal changes at selected locations, Mar. Chem., 164, 95-125, doi:10.1016/j.marchem.2014.06.004, 2014.

Tyrrell, T.: The relative influences of nitrogen and phosphorus on oceanic primary production, Nature, 400, 525-531, doi:10.1038/22941, 1999 .

545 Vance, D., Little, S. H., de Souza, G. F., Khatiwala, S., Lohan, M. C., and Middag, R.: Silicon and zinc biogeochemical cycles coupled through the Southern Ocean, Nat. Geosci., 10, 202-206, https://doi.org/10.1038/ngeo2890, 2017.

Woosley, R. J., and Millero, F. J.: Freshening of the western Arctic negates anthropogenic carbon uptake potential, Limnol. Oceanogr., doi:10.1002/lno.11421, 2020.

Wu, Y., Hain, M. P., Humphreys, M. P., Hartman, S., and Tyrrell, T.: What drives the latitudinal gradient in open-ocean surface dissolved inorganic carbon concentration?, Biogeosciences, 16, 2661-2681, doi:10.5194/bg-16-2661-2019, 2019. 